Article

\title{
Sprayer Axial Fan Layout Affecting Energy Consumption and Carbon Emissions
}

\author{
Sabina Failla ${ }^{1, *(\mathbb{C})}$, Carlo Bisaglia ${ }^{2}{ }^{\mathbb{C}}$, Giampaolo Schillaci ${ }^{1}$, Domenico Longo ${ }^{1}{ }^{\mathbb{C}}$ and \\ Elio Romano ${ }^{2} \mathbb{D}$ \\ 1 Department of Agriculture, Food and Environment (Di3A), Section of Mechanics and Mechanisation, \\ University of Catania, Via Santa Sofia 100, 95123 Catania, Italy; gschilla@unict.it (G.S.); dlongo@unict.it (D.L.) \\ 2 Consiglio per la Ricerca in Agricoltura e l'analisi dell'Economia Agraria-Centro di ricerca in Ingegneria e \\ Trasformazioni agroalimentari, Via Milano 43, 24047 Treviglio, Bergamo, Italy; \\ carlo.bisaglia@crea.gov.it (C.B.); elio.romano@crea.gov.it (E.R.) \\ * Correspondence: sfailla@unict.it
}

Received: 12 October 2020; Accepted: 19 November 2020; Published: 22 November 2020

check for updates

\begin{abstract}
Agricultural practices that make use of variable-rate (VR) distribution, introduced by precision agriculture (PA), are based on many points of variability which obtain different and modular effects that can affect the efficacy and environmental impact of the treatment performed. The aim of the present research was to study the effect of different structural combinations of an agricultural sprayer on the required power, fuel consumption, and carbon emissions. The studied machine was equipped with a mechanical device that regulated the air outlet section in three openings. The fan was tested in five blade angles and in two gear ratios. The power requirement $(\mathrm{kW})$ was calculated using a torque-meter. Moreover, fuel consumption $\left(\mathrm{L} \mathrm{h}^{-1}\right)$, energy demand $\left(\mathrm{MJ} \mathrm{L}^{-1}\right)$, and carbon emissions $\left(\mathrm{kg} \mathrm{CO}_{2} \mathrm{eq} \mathrm{kg}^{-1}\right.$ ) were calculated by the power consumption of each test. The results showed that all components of the layout and their interaction influenced consumption and, consequently, emissions. In order to mitigate the environmental impact of treatments, the outcomes suggest the possibility of implementing this study into algorithms that make setup choices during distribution.
\end{abstract}

Keywords: agricultural sprayer; plant protection treatments; energy savings; greenhouse gases; orchards

\section{Introduction}

The UNEP (United Nations Environment Programme) Emissions Gap Report 2019 [1] estimated that from 2020, the required cuts in global emissions needed to fight the increasing temperature are $2.7 \%$ per year for a $2{ }^{\circ} \mathrm{C}$ reduction goal and $7.6 \%$ per year on average for a $1.5^{\circ} \mathrm{C}$ reduction goal. For the European Union (EU), the $1.5^{\circ} \mathrm{C}$ goal would cause a $68 \%$ reduction in greenhouse gas (GHG) emissions by 2030 and exceed the current emission reduction objective by at least $40 \%$. Therefore, the European Commission is committed to reducing emissions by $50-55 \%$ by 2030 and to make Europe the first climate-neutral continent by 2050.

The agricultural sector represented a significant rate of EU emissions in 2015, with $\sim 460 \mathrm{MtCO}_{2} \mathrm{eq}$ or $12 \%$ of total GHG emissions, when including $\mathrm{CO}_{2}$ emissions from energy consumption in this sector. GHG emissions from the agricultural sector declined by $20 \%$ between 1990 and 2015 but there may still be room for improvement [2,3].

Energy consumption is a key question and source of impact in agricultural systems [4,5]. Demand for biofuels is also expected to rise and agriculture will be increasingly compromised by the combined effects of climate change and soil degradation [2]. In this context, more sustainable farming practices could represent a challenge to reduce emissions, costs, and pressure on biodiversity, as well as the pollution of air, water, and soil [6]. 
The European scenarios clearly highlight the trade-off between changing the demand for agricultural products and growing agricultural efficiency by increasing yields when possible without harming biodiversity and improving energy efficiency. Such technical measures are in line with the new European Commission "From Farm to Fork" strategy [7], which has, among others, the year 2030 targeted for ensuring sustainable food production by reducing the use and risk of chemical pesticides ( $50 \%$ by 2030 ) and fertilizer (at least $20 \%$ at 2030), as well as to enhance integrated pest management [8].

According to the 17 sustainable development goals (SDG) of the 2030 Agenda for Sustainable Development adopted by all United Nations Member States in 2015, sustainability is also sought in relation to agriculture (SDG 2). Pesticide application to crops and soils represents a constant source of pollutants in the atmosphere, soil, and water. In order to enhance the sustainability of crop protection treatments, precision agriculture (PA) practices continue to positively grow in importance, thus contributing to GHG emission mitigation, farm productivity, and economics.

The application of PA practices in agricultural field operations could positively contribute to GHG emission reduction due to a reduction in fuel consumption through less in-field operations with self-propelled machines (direct GHG decrease) and a reduction of inputs for agricultural operations (indirect GHG decrease) [9].

In order to reduce power consumption and drift losses during plant protection treatments in orchards, machines capable of operating air-assisted sprayers must be equipped with appropriate designs and fan settings, as well as with an air discharge system based on variable rate technology (VRT) [10-15]. Variable rate application of pesticides, supported by real-time canopy valuation, in tree fruit orchards and vineyards, has also been widely investigated [16-18]. Air-blast sprayers air volume settings have a significant role for correct spray deposition in the tree canopy during crop protection treatments, avoiding the spray drift [19-22].

Commonly, that operating manuals that are provided with sprayers do not offer information on the characteristics of generated air flow [23]. By contrast, the fan setting directly affects treatment quality. If air velocities or volumes produced by fans are too low, inadequate pesticides will reach the tree canopy; but, if these parameters are too high, the pesticide will be lost through the canopy.

Manufacturers and researchers have aimed to introduce the VRT solutions to empower the remote control of air parameters in real time during orchard treatments. Most sprayers only allow manual and discontinuous adjustments of fan-produced air volume. Thus, the disconnection of the tractor power take-off (PTO) to adjust a fan's transmission impeller blade angle or gear change of gear has been requested [13].

Some sprayers are based on reducing the air outlet (or inlet) of the sprayer's fan, but this solution is not energy efficient, because confining airflow increases power consumption. An innovative VRT air-jet adjustment and energy saving system was proposed by Doruchowski et al. [24] and Holownicki et al. [13] by means of a continuous real-time adjustment of air volume system mounted on both sides of the sprayer. The system used variable speed impellers with fixed blades, and it showed greater suitability than a method with adjustable pitch blades working at a constant speed. This was because it provided a wider range of air volumes and the power consumption did not exceed $10 \mathrm{~kW}$.

The main criteria for the suitability of VRT air-jet systems arises not only from remote air-flow control during orchard treatments but also from its adjustment range, which is suitable to lesser consumption [13].

From a PA perspective, the aim of the present paper was to evaluate energy consumption and emissions for different axial fan layouts commonly used in orchards via laboratory tests in repeatable conditions. The final objective was to find the best fan layout settings in order to reduce power consumption and harmful emissions. It is notable to highlight that a zero-carbon economy is more resilient due to a lower dependency on energy, raw material imports, and the volatility of fossil fuel prices, in addition to the improvement in public health, reduced energy bills, and the preservation of biodiversity. 
Moreover, the results of this study could drive the operational choices of farmers during crop protection treatments even if the treatment efficacy, in terms of deposit on the canopy, will be evaluated in further studies. The present study, in fact, is part of a larger research project that concerns the evaluation of axial fan sprayer efficiency from a PA perspective.

\section{Materials and Methods}

\subsection{The Laboratory for Measurements}

The experimental research was carried out in June and July 2019 at the inspection center for sprayers and sprayer machine manufacturers "Officina Antonino Turrisi", located in the Catania province in eastern Sicily (Italy).

The tests were carried out with an axial helical fan $(700 \mathrm{~mm}$ diameter), with 8 polyethylene blades (130 mm long), usually mounted on conventional sprayer machines (hydraulic pulverization) that were used in vineyards and orchards (Figure 1a). The blades had an adjustable pitch that assumed five different angles: 20, 26, 33, 40, and 44 degrees, as reported in Failla et al. [25].

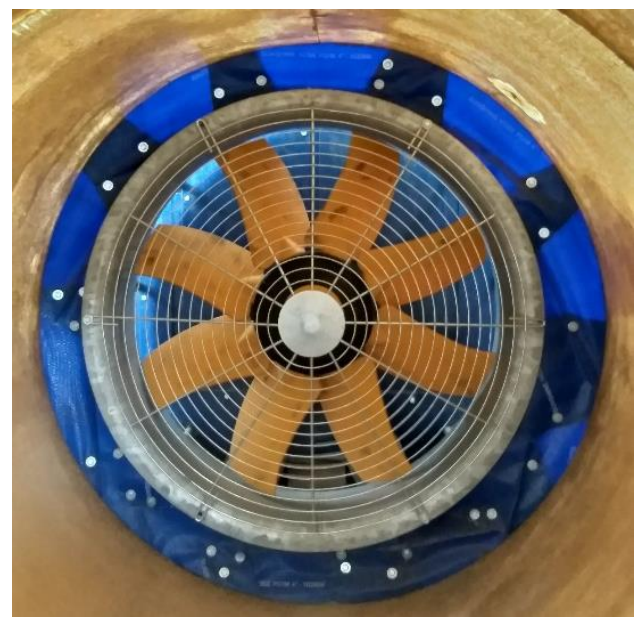

(a)

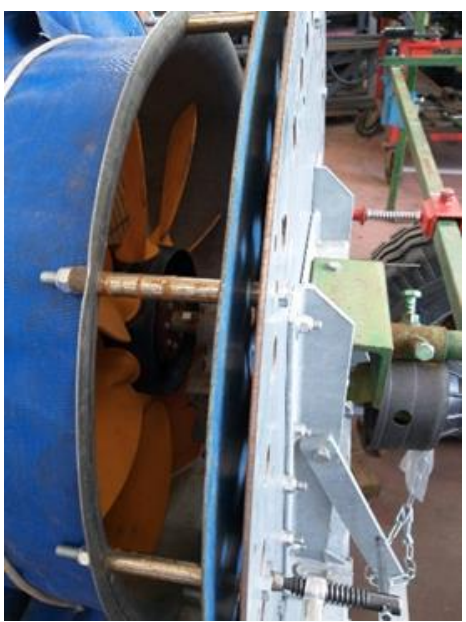

(b)

Figure 1. (a) The axial helical fan used in our study; (b) The metal panel behind the fan.

The nominal air output was $38,000 \mathrm{~m}^{3} \mathrm{~h}^{-1}$ with a nominal tractor power of $29 \mathrm{~kW}$. The fan was powered by a tractor PTO at $56 \mathrm{rad} \mathrm{s}^{-1}$ via a gearbox with two transmission ratios $\left(\tau_{1}=3.8\right.$ and $\left.\tau_{2}=4.53\right)$. For the first multiplicator gear, the rotational speed of the fan was about $216 \mathrm{rad} \mathrm{s}^{-1}$, while it was $256 \mathrm{rad} \mathrm{s}^{-1}$ for the second multiplicator gear. The tractor used during the tests was a 4WD narrow tractor model 3050DT (Goldoni, Modena, Italy) with $35 \mathrm{~kW}$ nominal power.

The outlet section of the air volume was adjusted using a purpose designed metal panel from 40 to $110 \mathrm{~mm}$ positioned behind the fan (Figure 1b). A torque-meter (HBM mod. T30FN, Darmstadt, Germany) with $3 \mathrm{kNm}$ nominal torque and $50 \mathrm{~Hz}$ (3000 rpm) nominal rotational speed was used to measure torque and rotational speed for the tractor PTO (Figure 2a). This was done to calculate the energy requirements during fan operation at different layouts [26]. The record array of the torque-meter was based on a multi-channel, in-vehicle data acquisition system DAS2-A8D (Datron Technology, Milton Keynes, UK) connected to a laptop personal computer (Figure 2b) [27].

\subsection{Experimental Tests}

The tests were carried out with the blade pitch angle set most used by farmers ( 40 degrees) compared with other possible blade pitch angles $(20,26,33$, and 44 degrees); two fan gear ratios $\left(\tau_{1}=3.8\right.$ and $\left.\tau_{2}=4.53\right)$ were used. The width of fan outlet section was adjusted based on the maximum opening $(110 \mathrm{~mm})$, the average $(60 \mathrm{~mm})$ and the minimum $(40 \mathrm{~mm})$, allowed by the specially designed 
system (Figure 1b). Thirty tests were performed by combining these layouts, as shown in Table 1. Each test lasted about 12 min on average.


Figure 2. (a) The torque-meter connected to the power take-off (PTO); (b) The acquisition system of the torque-meter.

Table 1. Layout of the 30 tests.

\begin{tabular}{|c|c|c|}
\hline Gear Ratio $(\tau)$ & Blade Angle (Degree) & Outlet Section (mm) \\
\hline \multirow{5}{*}{$\tau_{1}(3.8)$} & $20^{\circ}$ & $\begin{array}{c}40 \\
60 \\
110\end{array}$ \\
\hline & $26^{\circ}$ & $\begin{array}{c}40 \\
60 \\
110\end{array}$ \\
\hline & $33^{\circ}$ & $\begin{array}{c}40 \\
60 \\
110\end{array}$ \\
\hline & $40^{\circ}$ & $\begin{array}{c}40 \\
60 \\
110\end{array}$ \\
\hline & $44^{\circ}$ & $\begin{array}{c}40 \\
60 \\
110\end{array}$ \\
\hline \multirow{5}{*}{$\tau_{2}(4.53)$} & $20^{\circ}$ & $\begin{array}{c}40 \\
60 \\
110\end{array}$ \\
\hline & $26^{\circ}$ & $\begin{array}{c}40 \\
60 \\
110\end{array}$ \\
\hline & $33^{\circ}$ & $\begin{array}{c}40 \\
60 \\
110\end{array}$ \\
\hline & $40^{\circ}$ & $\begin{array}{c}40 \\
60 \\
110\end{array}$ \\
\hline & $44^{\circ}$ & $\begin{array}{c}40 \\
60 \\
110\end{array}$ \\
\hline
\end{tabular}




\subsection{Data Analysis}

The used torque-meter continuously monitored the signals from the tractor PTO and converted the analogue torque $(\mathrm{Nm})$ and speed signal $\left(\mathrm{rad} \mathrm{s}^{-1}\right)$ to digital values displayed on the computer monitor. The displayed values were stored in files on an SD card, which was then extracted in the processing phase. After the experimental test, the data were processed for the evaluation of any off-scale values and any acquisition defects.

The power $(\mathrm{kW})$ required during the compared tests were obtained from the torque and angular speed values recorded throughout the trials.

In order to calculate the tractor fuel consumption, the following equation, proposed by Grisso et al. [28], was used:

$$
\mathrm{Q}=(0.22 \mathrm{X}+0.096)\left(1-\left(-0.0045 \times \mathrm{N}_{\text {red }}+0.00877 \mathrm{~N}_{\text {red }}\right)\right) \times \mathrm{P}_{\text {pto }}
$$

where $\mathrm{Q}=$ diesel fuel consumption at a partial load $\left(\mathrm{L} \mathrm{h}^{-1}\right) ; \mathrm{X}=$ the ratio of equivalent PTO power (measured) to rated PTO power ( $90 \%$ of nominal tractor power); $\mathrm{N}_{\text {red }}=$ the percentage of reduced engine speed for a partial load from full throttle $(20 \%) ; \mathrm{P}_{\text {pto }}=$ the rated PTO power $(\mathrm{kW})$.

For this purpose, the rated PTO power of the tractor was considered equivalent to the $90 \%$ of its engine nominal power [29].

The fuel consumption of each test was considered to obtain the value of the $\mathrm{CO}_{2 e q}$ emissions by multiplying $3.728 \mathrm{~kg}$ for every $\mathrm{kg}$ of diesel consumed; this value included emissions derived from combustion and extraction, as well as refining processes (Ecoinvent database ver. 3.5) [30].

Moreover, in order to identify the optimal configuration of the fan with regard to energy saving, energy consumptions were calculated from liters of diesel consumed, assuming that each liter of diesel corresponds to $56.31 \mathrm{MJ}$ of energy [4,31].

All data were statistically analyzed with the open source software R [32]. The ANOVA was performed to test the main effect of the different fan configurations. The statistically significant difference between tests was estimated using the "laercio" package of $\mathrm{R}$ to develop a Tukey test with probability levels of $p \leq 0.05$ and $p \leq 0.01$.

\section{Results}

The results of the analysis of variance show that the effects of the gear ratio, the blade angle and the outlet section on the power and fuel consumption, energy use and emissions were statistically significant at $p=0.001$ (Table 2). The interactions between the variables are also statistically significant at $p=0.001$.

The variables shown in Table 2 (i.e., power and fuel consumption; energy use and emissions) were statistically influenced by both the gear ratio and the blade angle, as expected, but also, to a lesser extent, by the outlet section. Often, there were no statistically significant differences between the different outlet sections at the same blade angles. When there were differences, they were small.

The relationship between the power consumption and interaction blade angles $\times$ outlet section was evident (Table 2). The greatest power consumption derived from the $40 \mathrm{~mm}$ outlet section (smaller) at $20^{\circ}$, from the $60 \mathrm{~mm}$ outlet section (intermediate) at $26^{\circ}$, from the $110 \mathrm{~mm}$ outlet section (larger) at $33^{\circ}$, from the $60 \mathrm{~mm}$ outlet section at $40^{\circ}$, and from the 110 outlet section at $44^{\circ}$. This occurred within both gear ratios.

At the first multiplicator gear, the minimum value $0.77 \mathrm{~kW}$ was recorded at $20^{\circ}$, the maximum value $10.25 \mathrm{~kW}$ was recorded at $44^{\circ}$, and both were recorded at the $110 \mathrm{~mm}$ outlet section. At the second multiplicator gear, the minimum value $1.94 \mathrm{~kW}$ was recorded at $20^{\circ}$ and at the $110 \mathrm{~mm}$ outlet section while the maximum value was recorded at $44^{\circ}$ at $60 \mathrm{~mm}(13.43 \mathrm{~kW})$ and the $110 \mathrm{~mm}(12.70 \mathrm{~kW})$.

As shown in Table 2, fuel consumption increased when blade angles increase in both transmission ratios. At $\tau_{1}$, fuel consumption remained around $3 \mathrm{~L} \mathrm{~h}^{-1}$ at $20^{\circ}$ and $26^{\circ}$ to reach about $4-5 \mathrm{~L} \mathrm{~h}^{-1}$ with the other blade angles. At $\tau_{2}$, fuel consumption was about $4 \mathrm{~L} \mathrm{~h}^{-1}$ at $20^{\circ}$ and $26^{\circ}$ blade angles to go 
beyond $5 \mathrm{~L} \mathrm{~h}^{-1}$ with other inclinations. This meant an increase in fuel consumption of about $65 \%$, which passed from $20^{\circ}$ to $44^{\circ}$ at $\tau_{1}$ and more than $45 \%$ at $\tau_{2}$.

Similarly, energy demand and emissions followed the same trend (Table 2). At $\tau_{1}$, energy demand and emissions remained around $180-190 \mathrm{MJ} \mathrm{L}^{-1}$ and $10-11 \mathrm{kgCO}_{2} \mathrm{eq} \mathrm{kg}{ }^{-1}$, respectively, with the $20^{\circ}$ and $26^{\circ}$ blade angles growing to $260-290 \mathrm{MJ} \mathrm{L}^{-1}$ and $14-16 \mathrm{kgCO}_{2} \mathrm{eq} \mathrm{kg}^{-1}$. At $\tau_{2}$, the same parameters had higher values, going from about $200 \mathrm{MJ} \mathrm{L}^{-1}$ and $11-12 \mathrm{kgCO}_{2} \mathrm{eq} \mathrm{kg}^{-1}$ to over $300 \mathrm{MJ} \mathrm{L}^{-1}$ and $16-18 \mathrm{kgCO}_{2} \mathrm{eq} \mathrm{kg}^{-1}$ with the other blade angles.

On average, when passing from $20^{\circ}$ to $44^{\circ}$ blade angles with $\tau_{1}$, there was a $65 \%$ increase in energy demand and emissions. There was a $69 \%$ increase in energy demand and emissions about, passing from $20^{\circ}$ to $44^{\circ}$ with $\tau_{2}$.

The effects of the gear ratio on power and fuel consumption, energy use, and emissions were statistically significant at $p=0.001$, as shown in Figure 3 .

Table 2. Power and fuel consumption, energy use, and emissions in the 30 tests.

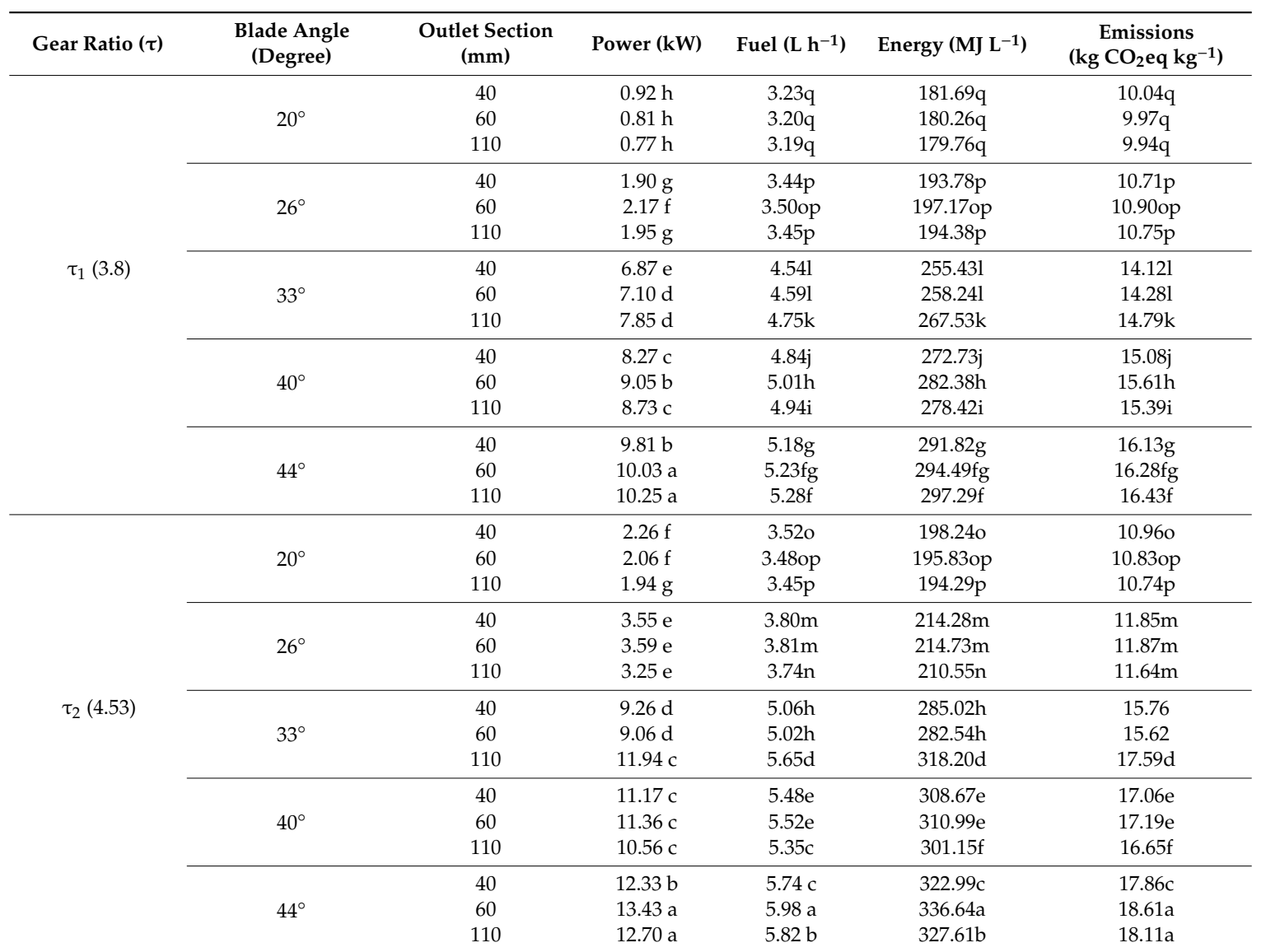

Letters (a-q) show between power significant difference at $p=0.001$ as determined by the Tukey test.

On average, statistically lower average values equal to $5.76 \mathrm{~kW}, 4.29 \mathrm{~L} \mathrm{~h}^{-1}, 241.20 \mathrm{MJ} \mathrm{L}^{-1}$, and $13.36 \mathrm{~kg} \mathrm{CO}_{2} \mathrm{eq} \mathrm{kg}^{-1}$ were recorded using $\tau_{1}$ in comparison to $8.06 \mathrm{~kW}, 4.80 \mathrm{~L} \mathrm{~h}^{-1}, 269.62 \mathrm{MJ} \mathrm{L}^{-1}$, and $14.93 \mathrm{~kg} \mathrm{CO}_{2} \mathrm{eq} \mathrm{kg}^{-1}$ recorded using $\tau_{2}$. In general, this meant that the use of the first multiplicator gear allowed us to save about $0.51 \mathrm{~L} \mathrm{~h}^{-1}$ of diesel fuel, $28.4 \mathrm{MJ} \mathrm{L}^{-1}$, and about $1.57 \mathrm{~kg} \mathrm{CO}_{2} \mathrm{eq} \mathrm{kg}^{-1}$ compared to the use of the second multiplicator gear (Figure 3).

The effects of the different blade angles on power and fuel consumption, energy use, and emissions were statistically significant at $p=0.001$, as shown in Figure 4 . 



Figure 3. Power required, fuel consumption, energy use, and emissions at the two transmission ratios. Letters $(\mathbf{a}, \mathbf{b})$ show between transmission ratio significant difference at $p=0.001$ as determined by the Tukey test.

On average, the transition from the smaller angles of $20^{\circ}$ and $26^{\circ}$ to those bigger at $33^{\circ}, 40^{\circ}$, and $44^{\circ}$ statistically increased the power consumption, passing from $1.46 \mathrm{~kW}$ at $20^{\circ}$ to $11.42 \mathrm{~kW}$ at $44^{\circ}$. Further, intermediate power consumption passed from $2.73 \mathrm{~kW}$ at $26^{\circ}$ to $8.68 \mathrm{~kW}$ at $33^{\circ}$ and to $9.96 \mathrm{~kW}$ at $40^{\circ}$ (Figure 4).

Similarly, this transition was statistically significant and increased fuel consumption, passing from $3.34 \mathrm{~L} \mathrm{~h}^{-1}$ at $20^{\circ}$ to $5.54 \mathrm{~L} \mathrm{~h}^{-1}$ at $44^{\circ}$ and intermediate fuel consumption of $3.62 \mathrm{~L} \mathrm{~h}^{-1}$ at $26^{\circ}$, $4.93 \mathrm{~L} \mathrm{~h}^{-1}$ at $33^{\circ}$, and $5.21 \mathrm{~L} \mathrm{~h}^{-1}$ at $40^{\circ}$. In terms of energy demand and emissions, $187.83 \mathrm{MJ} \mathrm{L}^{-1}$ and $10.41 \mathrm{~kg} \mathrm{CO}_{2} \mathrm{eq} \mathrm{kg}^{-1}$ was resulted at $20^{\circ} ; 203.66 \mathrm{MJ} \mathrm{L}^{-1}$ and $11.28 \mathrm{~kg} \mathrm{CO}_{2} \mathrm{eq} \mathrm{kg}^{-1}$ at $26^{\circ} ; 277.50 \mathrm{MJ} \mathrm{L}^{-1}$ and $15.36 \mathrm{~kg} \mathrm{CO}_{2} \mathrm{eq} \mathrm{kg}^{-1}$ at $33^{\circ} ; 293.00 \mathrm{MJ} \mathrm{L}^{-1}$ and $16.23 \mathrm{~kg} \mathrm{CO}_{2} \mathrm{eq} \mathrm{kg}^{-1}$ at $40^{\circ}$; and $311.17 \mathrm{MJ} \mathrm{L}^{-1}$ and $17.24 \mathrm{~kg} \mathrm{CO}_{2} \mathrm{eq} \mathrm{kg}^{-1}$ at $44^{\circ}$ (Figure 4).

On average, passing from $26^{\circ}$ to $33^{\circ}$, there was an increase of more than $200 \%$ in terms of power consumption and about $37 \%$ in terms of fuel expenditure, energy demand, and emissions. It is important to highlight that the $40^{\circ}$ blade angle was most used by farmers during orchard treatments, and it appeared to be among the most energy-intensive and emission-intensive layout. 

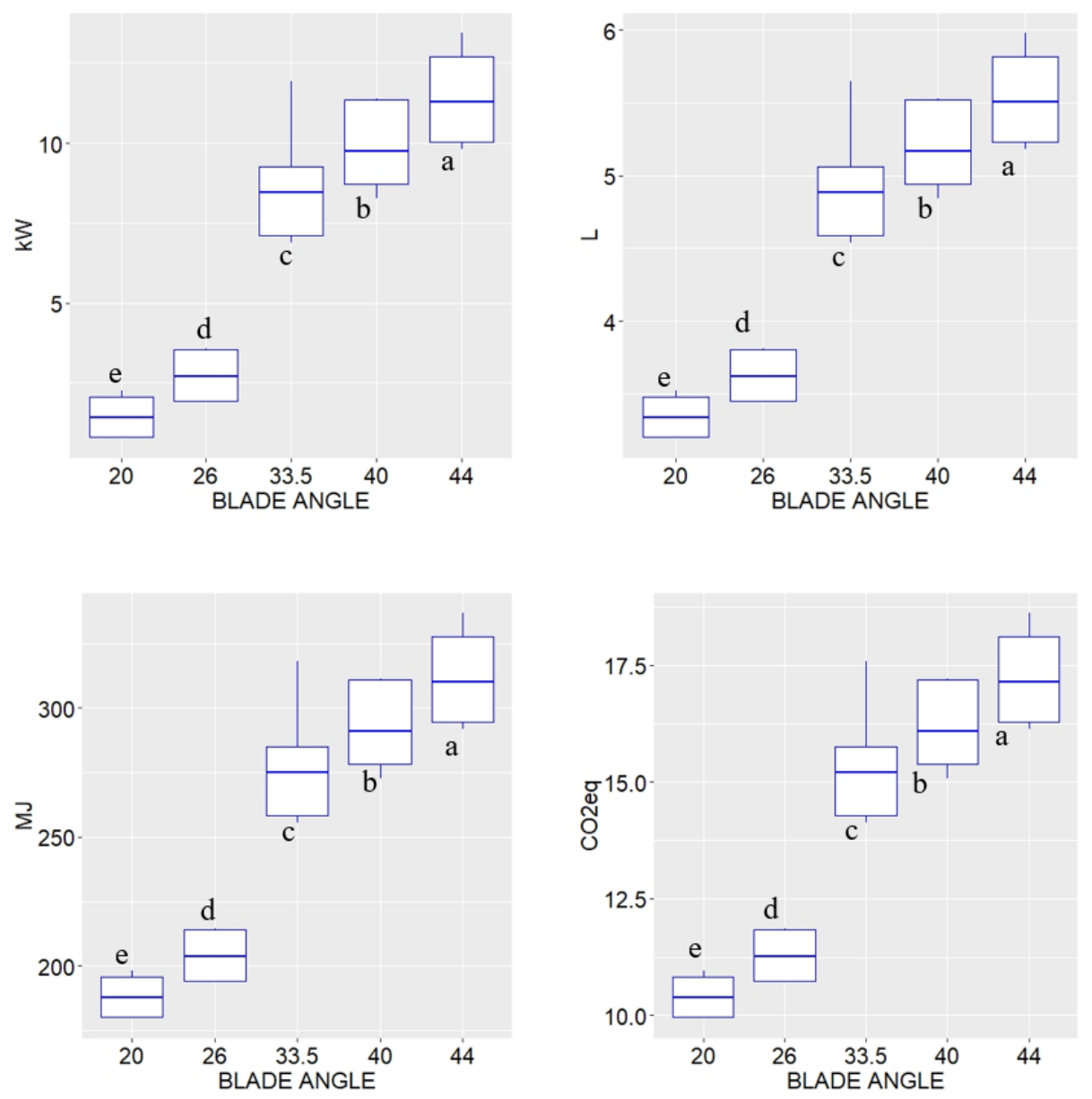

Figure 4. Power required, fuel consumption, energy use, and carbon emissions at different blade angles. Letters $(\mathbf{a}-\mathbf{c})$ show between blade angles significant difference at $p=0.001$ as determined by the Tukey test.

The fan's power consumption at the different blade angles was similar to the fan tested by Holownicki et al. [13]. They found a power consumption of $3.7 \mathrm{~kW}$ at $20^{\circ}, 6.2 \mathrm{~kW}$ at $32^{\circ}$, and $12.6 \mathrm{~kW}$ at $45^{\circ}$ with a fan of $600 \mathrm{~mm}$ diameter. This lower power consumption was attributed to the deflector of the prototype fan which had no internal plates and vanes, as it did in our study.

The different outlet section of the air volume produced statistically different power consumption, according to the Tukey test, returning an average value of $6.63 \mathrm{~kW}$ in the case of the smaller outlet section $(40 \mathrm{~mm}), 6.86 \mathrm{~kW}$ with the medium one $(60 \mathrm{~mm})$, and $7.31 \mathrm{~kW}$ with the largest one $(110 \mathrm{~mm})$. Between the smaller section and the larger one, there was a difference of $0.68 \mathrm{~kW}$; the smaller section led to about $10 \%$ less power consumption than the larger outlet section and about $3 \%$ less than the intermediate one (Figure 5).

Even in the case of fuel consumption $\left(4.48,4.53\right.$ and $\left.4.63 \mathrm{~L} \mathrm{~h}^{-1}\right)$, energy demand (251.90-254.80-260.45 MJ L-1), and emissions (13.96-14.11-14.42 $\mathrm{kg} \mathrm{CO}_{2} \mathrm{eq} \mathrm{kg}{ }^{-1}$ ), there were only slight differences between the average data, even if they were statistically significant. Therefore, in the test conditions, the layout relating to the outlet section did not have a crucial influence on power and fuel consumption, nor did it have one on energy use or harmful emissions.

Figure 6 summarizes the trend of power consumption by varying the gear ratios, the blade angles, and the outlet section. As already discussed, all other parameters analyzed above derived from this power consumption trend. 


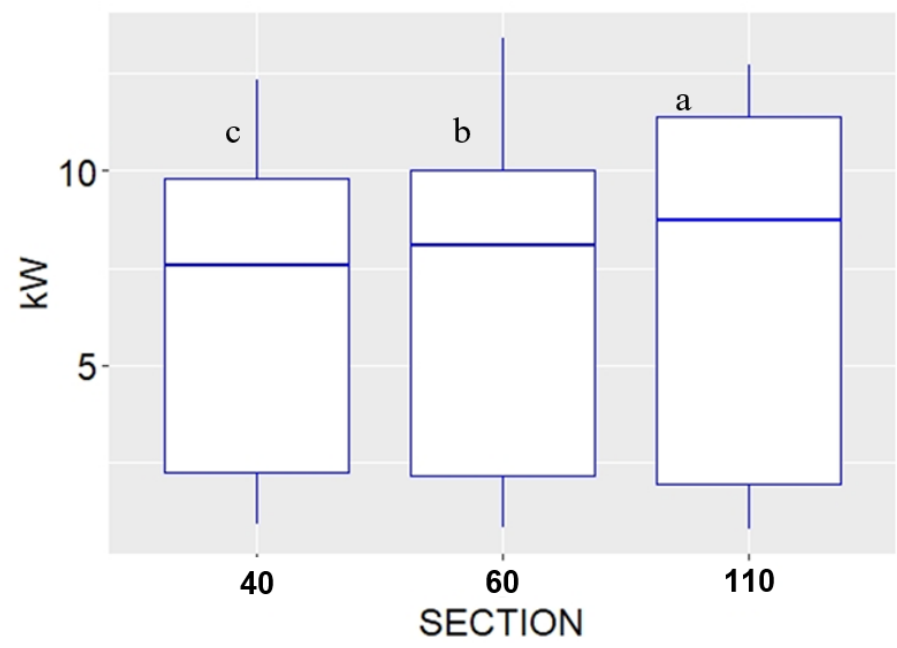

Figure 5. Power required at the three outlet sections $(\mathrm{mm})$. Letters $(\mathbf{a}-\mathbf{c})$ show between outlet sections significant difference at $p=0.001$ as determined by the Tukey test.


Figure 6. Power required at all layouts. Letters (a-e) show between blade angles significant difference at $p=0.001$ as determined by the Tukey test.

As shown in Figure 6, the general trend was characterized by the increase in power consumption as the blade angles increased. This was particularly evident in the transition between $26^{\circ}$ and $33^{\circ}$, especially in the $110 \mathrm{~mm}$ outlet section and with $\tau_{2}$. It was also evident that, with the same blade angles, the average values were always higher with the use of the second multiplicator gear, which was used most by farmers for plant protection treatments.

From an environmental impact point of view, focusing on emissions $\left(\mathrm{kgCO}_{2} \mathrm{eq} \mathrm{kg}{ }^{-1}\right)$ at different blade angles and gear ratios (Figure 7) proves that emissions increase in a linear positive mode when blade angles increase. This consideration was even more pronounced with the $\tau_{2}$, where the straight line of the values increased its inclination with increasing blade angles. 


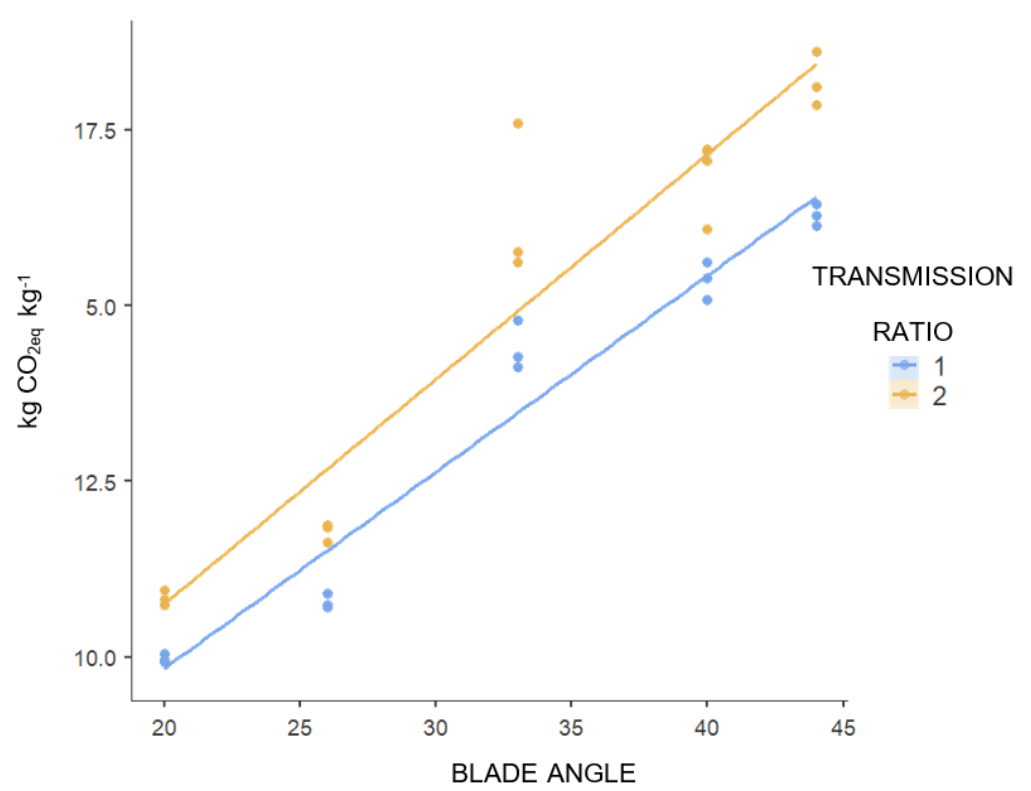

Figure 7. Emissions $\left(\mathrm{kgCO}_{2} \mathrm{eq} \mathrm{kg}^{-1}\right)$ at different blade angles and gear ratios.

Lal [33] reported that the equivalent carbon emission $\left(\mathrm{kg} \mathrm{CE} \mathrm{ha}^{-1}\right)$ in a field spraying operations was on average about $1.4 \mathrm{~kg} \mathrm{CE} \mathrm{ha}^{-1}$, indicating about $51.4 \mathrm{kgCO}_{2} \mathrm{eq} \mathrm{ha}^{-1}$ for the cultivation operation as a whole.

In our study, considering an average working capacity of 5 ha (hectares) per hour in the vineyard, the emissions amounted to about $20.45 \mathrm{kgCO}_{2} \mathrm{eq} \mathrm{ha}{ }^{-1}$ for $\tau_{2}$ and $13.12 \mathrm{kgCO}_{2} \mathrm{eq} \mathrm{ha}^{-1}$ for $\tau_{1}$. These emissions were related only to the consumption of diesel fuel needed to use the fan with the first or with the second gear ratio. To these emissions, the consumptions and relative emissions linked to the advancement of the tractor-operator complex, as well as to the functioning of other components in the spraying machine.

In summary, the energy demand and related emissions grew when the inclination angle increased. If we consider the maximum output section $(110 \mathrm{~mm})$, the percentage of absorbed power with respect to the nominal one was equal to $2 \%$ for $\tau_{1}$ and $5 \%$ for $\tau_{2}$ at $20^{\circ} ; 6 \%$ for $\tau_{1}$ and $9 \%$ for $\tau_{2}$ at $26^{\circ} ; 22 \%$ for $\tau_{1}$ and $34 \%$ for $\tau_{2}$ at $33^{\circ} ; 25 \%$ for $\tau_{1}$ and $30 \%$ for $\tau_{2}$ at $40^{\circ}$; and to $29 \%$ for $\tau_{1}$ and to $36 \%$ for $\tau_{2}$ at $44^{\circ}$. With the greater inclination, the power required for functionality became excessive, especially with $\tau_{2}$.

In the future, these data will be discussed in comparison with the air flow rate for the same sprayer axial fan layout in order to identify the optimal angle that guarantees efficient power consumption and air volume for suitable plant protection treatments.

\section{Conclusions}

The aim of the present paper was to evaluate the energy consumption and emissions of different axial fan sprayer layouts that are common in orchards. We evaluated these layouts via laboratory tests. The tests made it possible to highlight concerns we had with the fan (i.e., diameter $700 \mathrm{~mm}$ and standard blade profile), as well as the relationships between the three parameters relating to the fan layout (e.g., blade angle, outlet section) and use (gear ratio) of power, energy, and $\mathrm{CO}_{2}$ emissions.

The results showed that all components of the fan's layout and their interaction influenced consumption and, consequently, energy use and carbon emissions.

In general, lower power consumption was achieved with lesser blade angles $\left(20^{\circ}\right.$ and $\left.26^{\circ}\right)$ when both gear ratios and consumption levels increased, especially when they passed from $26^{\circ}$ to $33^{\circ}$. There was also a certain relationship between the inclination angle and the outlet section. Some combinations were more energy-intensive than others with the same inclination, even if the outlet section did not seem to determine notable differences at the same blade angles. 
It is important to point out that, on average, when passing from $20^{\circ}$ to $44^{\circ}$ degrees at $\tau_{1}$, there was a $65 \%$ increase in energy demand and emissions, as well as a $69 \%$ increase in the energy demand and emissions at $\tau_{2}$. In common practice, the second gear ratio was used most in air-assisted sprayers with inclinations at $33^{\circ}$ and $40^{\circ}$, probably because a greater volume of air was obtained without a real need linked to the canopy dimension. An excessive air volume led to higher operating costs without any benefit to distribution quality and by increasing drift issues.

Further studies should focus on air-flow profile measurements, which could be carried out in vineyards at different growing stages. The aim should be to find solutions that can combine reduced fossil energy use and variable air volumes in relation to the tree canopy.

From a PA perspective, this study could be implemented into algorithms that make setup choices during field treatments to reduce their environmental impact.

Author Contributions: Conceptualization, S.F., E.R., and G.S.; data curation, S.F. and E.R.; investigation, S.F., E.R., D.L., and G.S.; methodology, S.F., C.B., and E.R.; project administration, S.F.; supervision, C.B. and G.S.; writing-original draft, S.F., E.R., and C.B.; writing-review and editing, S.F. and E.R. All authors have read and agreed to the published version of the manuscript.

Funding: This research was funded by University of Catania (Italy).

Acknowledgments: The authors wish to acknowledge the "Officina Antonino Turrisi" in the Catania province (Sicily, Italy) for hosting the experimental tests. The activity presented in the paper was part of the research project titled "Innovazioni attraverso applicazioni ICT nel settore delle costruzioni rurali, della pianificazione del territorio agro-forestale e della meccanizzazione della difesa fitosanitaria. WP1-Sviluppo di tecniche e di applicazioni anche informatiche per l'innovazione nel settore della meccanizzazione della difesa fitosanitaria." Piano della Ricerca 2016-2018 of the University of Catania (Italy).

Conflicts of Interest: The authors declare no conflict of interest.

\section{References}

1. UNEP-United Nations Environment Programme. The Emissions Gap Report 2019. Available online: https://www.unenvironment.org/resources/emissions-gap-report-2019 (accessed on 14 September 2020).

2. CLIMACT. Increasing the EU's 2030 Emissions Reduction Target-June 2020. Available online: https://climact.com/wp-content/uploads/2020/06/Climact_Target_Emissions_report_FINAL.pdf (accessed on 14 September 2020).

3. EEA-European Environment Agency. 2017. Available online: https://ec.europa.eu/eurostat/statisticsexplained/pdfscache/16817.pdf (accessed on 29 September 2020).

4. Failla, S.; Ingrao, C.; Arcidiacono, C. Energy consumption of rainfed durum wheat cultivation in a Mediterranean area using three different soil management systems. Energy 2020, 195, 116960. [CrossRef]

5. Restuccia, A.; Failla, S.; Longo, D.; Caruso, L.; Mallia, I.; Schillaci, G. Assessment of energy return on energy investment (EROEI) of oil bearing crops for renewable fuel production. J. Agric. Eng. 2013, 44, 539-545. [CrossRef]

6. Recchia, L.; Sarri, D.; Rimediotti, M.; Boncinelli, P.; Cini, E.; Vieri, M. Towards the environmental sustainability assessment for the viticulture. J. Agric. Eng. 2018, 49, 19-28. [CrossRef]

7. European Commission. A Farm to Fork Strategy-For a fair, healthy and environmentally-friendly food system, Communication from the Commission to the European Parliament, the Council, the European Economic and Social, Committee and the Committee of the Regions, May 2020. Available online: https: //ec.europa.eu/food/farm2fork_en (accessed on 29 September 2020).

8. Papa, R.; Manetto, G.; Cerruto, E.; Failla, S. Mechanical distribution of beneficial arthropods in greenhouse and open field: A review. J. Agric. Eng. 2018, 49, 81-91. [CrossRef]

9. Balafoutis, A.T.; Beck, B.; Fountas, S.; Vangeyte, J.; Van Der Wal, T.; Soto, I.; Gómez-Barbero, M.; Barnes, A.P.; Eory, V. Precision Agriculture Technologies Positively Contributing to GHG Emissions Mitigation, Farm Productivity and Economics. Sustainability 2017, 9, 1339. [CrossRef]

10. Chen, Y.; Ozkan, H.E.; Zhu, H.; Derksen, R.C.; Krause, C.R. Spray deposition inside tree canopies from a newly developed variable-rate air-assisted sprayer. Trans. ASABE 2013, 56, 1263-1272. 
11. DeKeyser, D.; Duga, A.T.; Verboven, P.; Endalew, A.M.; Hendrickx, N.; Nuyttens, D. Assessment of orchard sprayers using laboratory experiments and computational fluid dynamics modelling. Biosyst. Eng. 2013, 114, 157-169. [CrossRef]

12. Delele, M.; Jaeken, P.; Debaer, C.; Baetens, K.; Endalew, A.M.; Ramon, H.; Nicolaï, B.; Verboven, P. CFD prototyping of an air-assisted orchard sprayer aimed at drift reduction. Comput. Electron. Agric. 2007, 55, 16-27. [CrossRef]

13. Hołownicki, R.; Doruchowski, G.; Świechowski, W.; Godyń, A.; Konopacki, P.J. Variable air assistance system for orchard sprayers; concept, design and preliminary testing. Biosyst. Eng. 2017, 163, 134-149. [CrossRef]

14. Khot, R.; Ehsani, R.; Albrigo, G.; Landers, A.J.; Larbi, P.A. Spray pattern investigation of an axial-fan airblast precision sprayer using a modified vertical patternator. Appl. Eng. Agric. 2012, 28, 647-654. [CrossRef]

15. Salcedo, R.; Garcera, C.; Granell, R.; Molto, E.; Chueca, P. Description of the airflow produced by an air-assisted sprayer during pesticide applications to citrus. Span. J. Agric. Res. 2015, 13, e0208. [CrossRef]

16. Chen, Y.; Han, J.; Zhao, X. Three-dimensional path planning for unmanned aerial vehicle based on linear programming. Robotica 2011, 30, 773-781. [CrossRef]

17. Gil, E.; Landers, A.; Gallart, M.; Llorens, J. Development of two portable patternators to improve drift control and operator training in the operation of vineyard sprayers. Span. J. Agric. Res. 2013, 11, 615. [CrossRef]

18. Gil, E.; Arnó, J.; Llorens, J.; Sanz, R.; Llop, J.; Rosell-Polo, J.R.; Gallart, M.; Escolà, A. Advanced Technologies for the Improvement of Spray Application Techniques in Spanish Viticulture: An Overview. Sensors 2014, 14, 691-708. [CrossRef]

19. Grella, M.; Marucco, P.; Balsari, P. Toward a new method to classify the airblast sprayers according to their potential drift reduction: Comparison of direct and new indirect measurement methods. Pest Manag. Sci. 2019, 75, 2219-2235. [CrossRef]

20. Moltó, E.; Chueca, P.; Garcerá, C.; Balsari, P.; Gil, E.; Van De Zande, J.C. Engineering approaches for reducing spray drift. Biosyst. Eng. 2017, 154, 1-2. [CrossRef]

21. Qiu, W.; Sun, C.; Lv, X.; Ding, W.; Feng, X. Effect of Air-assisted Spray Application Rate on Spray Droplet Deposition Distribution on Fruit Tree Canopies. Appl. Eng. Agric. 2016, 32, 739-749. [CrossRef]

22. van de Zande, J.C.; Michielsen, J.M.G.P.; Stallinga, H.; van Dalfsen, P.; Wenneker, M. Effect on air deposition and spray liquid distribution of a cross flow fan orchard sprayer on spray deposition in fruit trees. In Proceedings of the 7th European Workshop on Standardized Procedure for the Inspection of Sprayers in Europe, Athens, Greece, 24-26 September 2018.

23. García-Ramos, F.J.; Malón, H.; Aguirre, Á.J.; Boné, A.; Puyuelo, J.; Vidal, M. Validation of a CFD Model by Using 3D Sonic Anemometers to Analyse the Air Velocity Generated by an Air-Assisted Sprayer Equipped with Two Axial Fans. Sensors 2015, 15, 2399-2418. [CrossRef]

24. Doruchowski, G.; Swiechowski, W.; Godyn, A.; Hołownicki, R. Automatically controlled sprayer to implement spray drift reducing application strategies in orchards. J. Fruit Ornam. Plant Res. 2011, 19, 175-182.

25. Failla, S.; Romano, E.; Longo, D.; Bisaglia, C.; Schillaci, G. Effect of Different Axial Fans Configurations on Airflow Rate. Lect. Notes Civ. Eng. 2020, 67, 691-699.

26. Andersson, I.; Thor, M.; McKelvey, T. The torque ratio concept for combustion monitoring of internal combustion engines. Control Eng. Pract. 2012, 20, 561-568. [CrossRef]

27. Bisaglia, C.; Romano, E. Utilization of vineyard pruning: A new mechanization system from residues harvest to CHIPS production. Biomass Bioenergy 2018, 115, 136-142. [CrossRef]

28. Grisso, R.D.; Kocher, M.F.; Vaughan, D.H. Predicting tractor fuel consumption. Appl. Eng. Agric. 2004, 20, 553-561. [CrossRef]

29. Wilmer, H. All you need to know about diesel guzzling and engine power. Profi Int. 2001, 11, 40-42.

30. IPCC. IPCC Fifth Assessment Report (AR5) e The Physical Science Basis. 2013. Available online: https://www.cambridge.org/core/books/climate-change-2013-the-physical-science-basis/summaryfor-policymakers/356E277FD1FBC887845FB9E8CBC90CCD (accessed on 17 September 2020).

31. Unakitan, G.; Aydin, B. A comparison of energy use efficiency and economic analysis of wheat and sunflower production in Turkey: A case study in Thrace region. Energy 2018, 149, 279-285. [CrossRef] 
32. R Development Core Team. R: A Language and Environment for Statistical Computing; R Foundation for Statistical Computing: Vienna, Austria, 2012; Available online: http://www.R-project.org (accessed on 26 April 2019).

33. Lal, R. Carbon emission from farm operations. Environ. Int. 2004, 30, 981-990. [CrossRef] [PubMed]

Publisher's Note: MDPI stays neutral with regard to jurisdictional claims in published maps and institutional affiliations.

(C) 2020 by the authors. Licensee MDPI, Basel, Switzerland. This article is an open access article distributed under the terms and conditions of the Creative Commons Attribution (CC BY) license (http://creativecommons.org/licenses/by/4.0/). 